\title{
LINKING SHADE COFFEE CERTIFICATION TO BIODIVERSITY CONSERVATION: BUTTERFLIES AND BIRDS IN CHIAPAS, MEXICO
}

\author{
Alexandre H. Mas and Thomas V. Dietsch ${ }^{1}$ \\ School of Natural Resources and Environment, University of Michigan, Ann Arbor, Michigan 48109-1115 USA
}

\begin{abstract}
Shade coffee certification programs have emerged over the past six years to verify that coffee marketed as "shade grown" is actually grown on farms that provide higher quality habitat for biodiversity. In spite of good intentions and an increasing market, little consensus exists on whether current criteria can successfully identify coffee farms of conservation significance. This paper provides the first ecological evaluation and comparison of shade-grown coffee criteria used by major certification programs. Using vegetative data, we evaluated criteria developed by the Rainforest Alliance, the Smithsonian Migratory Bird Center (SMBC), and the Specialty Coffee Association of America across a range of coffee agroecosystems in Chiapas, Mexico, to determine which management practices each program would certify. Fruit-feeding butterflies and forest bird species found in these coffee agroecosystems were compared with nearby forest reserves as indicators of biodiversity and conservation potential. These agroecosystems fall into three categories: rustic, commercial polyculture, and shaded monoculture. The rustic system contained significantly higher fruit-feeding butterfly diversity and an avifauna more similar to that found in forest reserves than the other systems. This was also the only agroecosystem that met the criteria for all certification programs, while the shaded monoculture fell short of all sets of criteria. This suggests that certification programs are succeeding in discriminating between the extremes of shade coffee production. Certification programs differed, however, in their treatment of the intermediate, commercial polyculture systems, reflecting different philosophies for conservation in managed ecosystems. Programs promoted by SMBC use high standards that would exclude all but the most diverse commercial polyculture or rustic systems to certify only those systems that support high levels of biodiversity. The program supported by the Rainforest Alliance only excludes the shaded monoculture while engaging the others in the move toward greater sustainability. The merits of each approach should be put to rigorous debate, and their ability to contribute to biodiversity conservation should be reflected in product marketing. This study suggests that further research can provide a stronger scientific basis and independent verification for the certification of green products that claim to enhance biodiversity conservation in tropical agroecosystems.
\end{abstract}

Key words: biodiversity; certification; Chiapas, Mexico; coffee agroecosystems; forest birds; fruit-feeding butterflies; intensity gradient; market-based conservation; shade coffee.

\section{Biodiversity and Shade Coffee Plantations}

Traditional methods of coffee cultivation involve growing shade-preferring varieties of coffee under diverse forest canopies. These practices have been increasingly replaced by practices that use sun-favoring coffee varieties grown more densely in full sun or under the shade of a single species of tree (Perfecto et al. 1996). Often referred to as "rustic," these traditional shade coffee plantations provide an important refuge for biodiversity, especially compared to more intensive agricultural practices (Perfecto and Snelling 1995, Moguel and Toledo 1996, Perfecto et al. 1996, Wunderle and Latta 1996, Greenberg et al. 1997a, b, Mas and Dietsch 2003). Research and well-targeted efforts to

Manuscript received 10 July 2002; revised 20 May 2003; accepted 18 June 2003; final version received 8 August 2003. Corresponding Editor: A. R. Townsend.

${ }^{1}$ Present address: Smithsonian Migratory Bird Center, National Zoological Park, 3001 Connecticut Avenue NW, Washington, D.C. 20008 USA. educate the public have contributed to the development of a market for shade coffee in the United States estimated at \$10-\$100 million (U.S. \$) annually (CEC 1999, Rice and McLean 1999). While the increasing market for shade coffee is grounds for optimism, hope is tempered by the fact that, unlike organic and Fair Trade coffees, which enjoy well codified definitions and certification standards, the definition of "shade" coffee remains unclear (Rice and McLean 1999, Messer et al. 2000).

Clarifying this definition, as well as determining what kind of shade management contributes to biodiversity conservation, is critical for increasing consumers' confidence in shade coffee certification programs. For example, some plantations in Central America have a low density of heavily pruned Inga or Erythryna trees. Although these plantations contain shade trees, they are unlikely to be as effective at preserving biodiversity as rustic plantations that preserve the diversity and structural complexity of forests. In other words, not all 
shade is created equal and not all plantations which include a shade component, even those certified organic, are likely to provide significant conservation benefits.

To address the issue of how to better define shadegrown coffee, and to prevent cheaters in the system and a crash in consumer confidence, various farm certification programs have emerged over the past six years. These eco-labeling programs, each with distinct goals developed and promoted by organizations like Smithsonian Migratory Bird Center, Conservation International, and Rainforest Alliance, as well as by country-specific working groups, have brought together researchers, roasters, and farmers to establish more specific criteria for shade coffee production (Rice and McLean 1999). While ecologists have made progress on outlining relevant criteria (Rice and McLean 1999), consensus has only recently emerged on general criteria (Consumer's Choice Council et al. 2001), and each certification program still relies on criteria that reflect their distinct program goals and that are supported by limited research (see Appendix for ecological criteria). In general, these certification programs are attempting to provide economic incentives for farmers to maintain habitat characteristics that meet set criteria to provide habitat for biodiversity within the coffee production system. Previous research supports this approach to improving conservation within coffee agriculture (Perfecto et al. 1996). However, there has been no direct test of the hypothesis that coffee management systems which meet the specific criteria used by shade coffee certification programs support higher levels of biodiversity than those that do not.

Mas and Dietsch (2003) developed an index of management intensity that distinguishes between different shade coffee agroecosystems along an intensity gradient using data on the vegetative and structural diversity of the shade canopy to examine the impacts of shade management on butterfly species richness. This study evaluates each of these management systems using vegetative data from the previous study to determine if the system would qualify for certification by current shade coffee programs. The butterfly data are then used with additional data on birds to evaluate how effective the criteria used by these certification programs are at achieving biodiversity conservation goals.

\section{Shade Coffee Certification Programs}

Several shade coffee certification programs have been developed since the early 1990s, each with a different approach to engaging and certifying coffee producers (for a full review of these programs and their certification criteria see Mas 1999, Rice and McLean 1999). The ECO-O.K. program (which extends to other agricultural crops as well) was developed by the Rainforest Alliance with the general goal of promoting sustainable agriculture using an inclusive approach that uses attainable criteria to reach as many farmers as possible. This program encourages farmers to adopt best management practices and contains additional criteria other than those pertaining to the shade canopy, including regulation of chemical use, overall ecological integrity of the farm, and the living and working conditions of laborers on the farm (Rice and McLean 1999). A workshop organized in 1997 by El Salvador's newly created Ministry of the Environment and sponsored by the World Bank's Global Environment Facility used ECO-O.K.'s coffee criteria as an initial framework from which to build a new program for certifying "biodiversity-friendly" coffee in El Salvador. The resulting criteria have since been modified and are now used by ECO-O.K. for all of their coffee certification (C. Wille, personal communication).

The next program was developed by the Smithsonian Migratory Bird Center (SMBC) in an attempt to encourage conservation of habitat for Neotropical migratory birds in Latin America (Rice and McLean 1999). SMBCs program for certifying "Bird-Friendly" coffee uses rigorous criteria that were developed by a working group at the First Sustainable Coffee Congress in 1996 and relate exclusively to management of the shade canopy, though organic certification is a prerequisite to participation in the program. In February of 1999, SMBC organized an expert workshop in Xalapa, Mexico to develop another set of certification criteria specific to shade-grown coffee in Mexico (Commission for Environmental Cooperation 1999). The workshop, funded by the Commission for Environmental Cooperation, resulted in two new sets of standards, one of which sets minimum requirements for coffee to be certified as Mexican Shade and another which certifies exemplary farms, referred to here as Mexican Shade PLUS (names are tentative and may change when this program is put into effect). While the Mexican programs have not yet been formalized or implemented, the criteria developed present some new and innovative ways of quantifying a coffee farm's shade canopy, and thus merit inclusion in this study.

The final set of criteria included in this evaluation come from the draft definition of shade coffee proposed by the Environment Committee at the 1999 meeting of the Specialty Coffee Association of America (Rice and McLean 1999). These criteria are not in use, but have been recommended as a working definition of shade coffee for the specialty coffee industry. A recent paper produced jointly by Conservation International, Consumer's Choice Council, Rainforest Alliance, Smithsonian Migratory Bird Center, and the Summit Foundation outlines a common understanding for how coffee production can promote ecosystem and wildlife conservation in order to provide a conceptual umbrella over existing criteria, but specific certification criteria were intentionally not described (Consumer's Choice Council et al. 2001). Unfortunately, the use of the term shade grown is increasingly used to market uncertified products to consumers seeking "eco-friendly" prod- 
ucts. While this may aid efforts to increase consumer recognition in the short term, evaluation and certification of specific management practices linked to conservation benefits is necessary to create a credible market that can support higher prices for producers.

\section{Shade Coffee in Mexico}

Mexico is well suited for the evaluation of shade certification programs because $89 \%$ of the area where coffee is grown maintains some shade canopy, and $39 \%$ of the area is grown under diverse shade (Moguel and Toledo 1999). This is a striking figure when compared to two of the world's other top coffee producing countries, Colombia and Brazil, which have converted at least $68 \%$ of their coffee to full-sun production (Rice and Ward 1996). Furthermore, the classification system for shaded coffee plantations that has influenced the certification process was developed in Mexico (Toledo and Moguel 1996, Moguel and Toledo 1999). Mexico also has one of the longest traditions of small-farmer cooperatives in Latin America (Celis et al. 1991). Coffee cooperatives are among the most established and, in the primary coffee growing regions of Chiapas, Oaxaca, and Veracruz, these cooperatives have been innovators in organic and fair trade production (Celis et al. 1991, Pérezgrovas et al. 1997) and usually maintain communal lands in a forested reserve status. Mexico produces more certified organic coffee than any other country and, while not the focus of this study, organic coffee production techniques, which prohibit agrochemical use, provide an important complement to management of the shade overstory in conserving biodiversity, and as such are required for certification by SMBC (Kortbech-Olesen 2000, Bray et al. 2002). These factors make Mexico not only ideal for this study, but also uniquely positioned to take proactive steps to conserve traditional, shaded coffee farms.

\section{METHODS \\ Study sites}

Data for this study were collected at two sites on the Pacific side of the Sierra Madre mountain range in the Soconusco district of Chiapas, Mexico, one in the municipality of Tapachula and the other in Huixtla. Coffee in this region has almost completely replaced midelevation forests between 500 and $1500 \mathrm{~m}$ though many farms maintain small forest fragments or reserves. Based on Moguel and Toledo (1999), the following coffee management categories were included in the study: Rustic, Commercial Polyculture, and Shaded Monoculture. In Huixtla, two areas of coffee cultivation were sampled at Finca Belen, a rustic area with the original native overstory relatively intact (Belen Rustic) and an area of commercial polyculture (Belen Production), with Inga sp. and Alchornia latifolia most abundant in the overstory. In Tapachula, a similar area of commercial polyculture was sampled at Finca Irlan- da (Irlanda Production), as well as an area where the owner is planting additional native overstory trees into a commercial polyculture in an effort to restore a more diverse, native overstory (Irlanda Restoration). New trees in this area are still relatively young $(\sim 10-15$ years) and have not reached the stature to fit the category that Moguel and Toledo (1999) would identify as Traditional Polyculture. However, this treatment may represent an important transition stage as farmers restore a greater diversity of native trees to the overstory, so it is referred to here as "restoration."

A neighboring farm, Finca Hamburgo, was also included in the study because it represented the more intensive shaded monoculture production system (Hamburgo Production) using only Inga sp. for shade. This system was not certified organic but the owners have greatly reduced agrochemical use, only applying synthetic fertilizers infrequently during the study. All other treatments were certified organic to minimize confounding effects from the use of chemicals hazardous to insects and birds. Small reserves (20-30 ha) of relatively intact forest maintained by each owner were present and sampled at both sites (Irlanda Forest and Belen Forest). The reserves used were of an adequate size and shape to allow sample locations with minimal edge effects. Unfortunately, most midelevation (500$1500 \mathrm{~m}$ ) forest has already been converted to coffee agriculture, making comparisons to larger forest reserves impossible. Larger forest patches are found regionally, but only at higher elevations, where these forests support a different flora and fauna typically found in cloud forest ecosystems above $1750 \mathrm{~m}$ elevation. Table 1 summarizes the treatments included in the study. All sampling locations were situated near $1000 \mathrm{~m}$ in elevation $( \pm 100 \mathrm{~m})$. Sampling locations were randomly located and separated by a distance of 125-200 m with a minimum $75 \mathrm{~m}$ distance to edge with another management type. Minimum distances were based on size constraints in reserve areas and the restoration treatment.

\section{Biodiversity sampling and analysis}

During summer 1998, 10-min, 25-m fixed-radius point counts were conducted at each sampling location (Hutto et al. 1986, Petit et al. 1994). There were four sampling locations per treatment (in total, two forest reserves and five coffee management treatments). Each morning, beginning at dawn, point counts were visited in random order to minimize temporal bias. Multiple visits were used to improve the analytical connection between vegetation data from each sample location with corresponding bird data (Dettmers et al. 1999, Drapeau et al. 1999). Each sample location was visited on four separate days and all birds heard and seen were noted during each 10-min count with the exception of flying birds that did not begin or end flight within the $25 \mathrm{~m}$ radius. These were the same sample locations used to survey butterflies by Mas and Dietsch (2003). 
TABle 1. Management treatments (per Moguel and Toledo 1999) included in the study of coffee farms in Chiapas, Mexico, with the corresponding reference names used in this paper.

\begin{tabular}{llcc}
\hline \hline Management treatment & Name of farm & $\begin{array}{l}\text { Certified } \\
\text { organic? }\end{array}$ & Reference name \\
\hline Forest & Belen & NA & forest \\
Forest & Irlanda & NA & forest \\
Rustic & Belen & yes & rustic \\
Traditional polyculture & Irlanda & yes & restoration \\
Commercial polyculture & Belen & yes & production \\
Commercial polyculture & Irlanda & yes & production \\
Shaded monoculture & Hamburgo & no & production \\
\hline
\end{tabular}

In that study, two standard butterfly bait traps were set as close as possible to the center of each sampling location, one in the understory and one in the canopy, for a period of eight days and baited with a mash of fermented plantain or banana before each sampling day. Traps were checked on alternate days and each location was visited at approximately the same time of day to ensure an equal period of time between samples.

Following bird and butterfly sampling, the vegetation at each sampling location was characterized. The height and diameter at breast height (dbh) of all overstory trees $>3 \mathrm{~cm}$ dbh at each location were sampled within a $12 \mathrm{~m}$ radius. Understory trees and shrubs, including height and density of coffee, were sampled within a $5 \mathrm{~m}$ radius. Percent canopy cover was estimated using the LAI 2000 Plant Canopy Analyzer (LICOR, Lincoln, Nebraska, USA), and canopy structure was estimated using a method developed for determining an approximate canopy profile for each sampling location. A management index was then developed to quantify the effects of management on the shade canopy, including all of the vegetation variables determined to be affected by farm management activities. Slope, aspect, and the presence of epiphytes were also noted (see Mas and Dietsch [2003] for greater detail on vegetation sampling).

Mobility may lead to different responses between taxa, which result from variation in landscape position rather than habitat differences produced by management practices. A comparison of species richness of birds, butterflies, and ants in this same system suggested that bird species richness in coffee shows a stronger influence of distance from forest edge (Perfecto et al. 2003). This is further confounded by the regional trend of lower management intensity near forest reserves. To reduce this problem, bird diversity was evaluated using the Bray-Curtis dissimilarity index comparing each coffee management type and its associated forest reserve. The Bray-Curtis index is calculated using the abundance of each species that reduces the effect of a few transitory individuals from forest species not commonly found in a management type (Bray and Curtis 1957, Magurran 1988). By accounting for the abundance of each species, the change produced by a single transitory individual observed in coffee produces only a small change in the index compared to the total abundance observed and thus will not overrepresent the conservation benefits from coffee management for that species. Though for some conservation benefits, such as gene flow between populations, a transitory individual may represent a significant conservation contribution, this study focused on those conservation benefits accrued by regular use associated with breeding or foraging habitat. Hamburgo Production, Irlanda Restoration and Irlanda Production were compared to the Irlanda Forest while Belen Rustic and Belen Production were compared with the Belen Forest. This index produces a fraction between 0 and 1 with higher numbers (closer to 1) suggesting that the avifauna in a given management type is less similar to the avifauna found in its associated forest reserve. This dissimilarity index is then converted to a similarity index by subtracting the value from 1 . Greater similarity to the forest avifauna indicates that a management system is providing greater conservation benefits for those bird species most at risk from increasing management intensity of coffee. Analysis of variance (ANOVA) was used to compare management treatments using StatView v5.0.1 (SAS Institute 1998).

Butterfly species richness was compared using randomization programs written by M. E. Siddall to permute the order of acquisition of species used in constructing species accumulation curves (for a description and comparison of this method, see Payne et al. 2000). One hundred random permutations were performed to generate 100 estimates of total species richness, and these estimates were then randomly reassigned into two groups 10000 times using the software RANDMEAN (available online). ${ }^{2}$ RANDMEAN then evaluates how frequently it is possible to achieve the difference as great or greater than the actual difference observed, and uses this probability (Bonferroni transformed at $\alpha=0.05$ to adjust for compounding error rate) to derive the $P$ values of statistically significant difference.

\section{Evaluation of certification programs}

This study focused on biodiversity associated with growing practices, so only certification criteria that relate directly to the shade canopy are included in this evaluation. Some grouping of similar criteria into gen-

\footnotetext{
${ }^{2}$ URL: 〈http://research.amnh.org/ siddall/rand.html〉
} 
eral categories (see headings in the Appendix) was necessary to allow comparison due to variation in wording between programs. For example, all programs included criteria related to the "backbone" trees of the shade canopy, which are the trees of the same species or similar stature that dominate the shade on a given farm (SMBC 1998, CEC 1999, Rice and McLean 1999). The ECO-O.K. program focused on whether these trees were perennial or deciduous, while in the other programs the criteria centered on what percentage of that backbone was made up of a single species or genus of tree. Since these criteria all relate to the composition of the backbone shade trees, they were grouped and compared as such.

Average canopy height is also measured slightly differently by each certification program. The BirdFriendly program contains a criterion for the average height of the backbone, while the Mexican Shade program refers to the average canopy height, excluding obvious emergent trees. For the sake of comparison, these criteria were evaluated together, though it is important to bear in mind that they do not refer to precisely the same thing. Similar subtleties differentiate the comparison of structural diversity as measured by presence of a stratum of emergent trees. The Mexican Shade and ECO-O.K. programs both require this stratum of emergent trees, and set a minimum height, but the ECO-O.K. program additionally recommends that these emergent trees represent $20 \%$ of the canopy. The Bird-Friendly program presents the most complicated version by requiring that $20 \%$ of trees be taller, and $20 \%$ shorter than the backbone stratum. Again, for the sake of comparison, all versions were evaluated together under the heading, "Presence and Height of Emergent Trees."

Since most of the criteria are measured on a per hectare basis, some manipulation was necessary to transform the data collected for this study into a form that could be compared with the criteria. For tree density per hectare, the total number of trees for all four sampling locations within a management system were calculated and then converted to a per hectare value. Diversity of shade tree species was collected on the basis of 0.18 hectares of area, so a species accumulation curve should ideally be used to project the expected diversity of trees at an area of 1 ha. As a result, the tree species richness values included in this evaluation represent conservative estimates of the actual diversity.

To calculate the composition of backbone shade trees, percentage of trees at each sampling station that were of one dominant species was calculated, as was the percentage that were of the genus Inga, because this was the dominant genus used for coffee shade in the region (A. H. Mas and T. V. Dietsch, personal observation). To compare criteria relating to presence and height of emergent trees, the percent of the canopy that was taller than the backbone or average height was calculated, as well as the percent taller than $15 \mathrm{~m}$ and the presence of a stratum of trees taller than $20 \mathrm{~m}$. Percent canopy cover, average height of canopy, and percentage of trees with epiphytes present were all easily extracted from the data collected, and information on the season of pruning and restoration/conservation projects was taken from informal discussions with farm managers.

In all cases, if a program did not contain a criterion under a certain category it was labeled as having "no specific requirement" and not evaluated. In cases where criteria did exist, actual values for each management system were compared to criteria requirements of each program, and if they met the criteria they received a "pass," and if they could not meet the criteria, they received a "fail." If a management system came extremely close to meeting a criterion, it received a "borderline" mark, with the assumption that certification inspectors would make the ultimate decision on passing or failure somewhat subjectively. After evaluating all of the criteria, results for each management system were combined to see if coffee grown in that system would be certified or rejected by each certification program. It is important to restate that this evaluation reflects only the subset of criteria in each program that relate directly to the shade canopy, and management systems compared do not necessarily reflect distinct farms.

\section{Selection of certification programs}

Initially, we sought to provide an all-inclusive evaluation of certification programs. However, as the concept of shade-grown coffee has grown, so have the number of organizations marketing and certifying environmentally sensitive products. Consequently, for this analysis we focused on third party certification programs with publicly available criteria. Programs such as Seattle Audubon's Northwest Shade Coffee Campaign were not included because they allow selfcertification using nonspecific site visits and rely on criteria and certification from a mixture of other programs including those evaluated in this paper. Another well-publicized program not included was Conservation International's Conservation Coffee collaboration with the Starbucks Coffee Company because only guiding principles have been published (available online), ${ }^{3}$ and specific criteria testable using the methods described here are not available. The same holds true for the recently published agreement on conservation principles for coffee production (Consumer's Choice Council et al. 2001).

\section{RESUlts}

\section{Evaluation of certification programs}

Table 2 presents the overall evaluation of the shade management systems included in this study by each

${ }^{3}$ URL: 〈http://www.celb.org/pressreleases/ ConservationCoffeeFactsheet5-22.pdf $\rangle$ 
TABLE 2. Final certification evaluations for the five coffee management systems based on criteria of four shade coffee certification programs and the Specialty Coffee Association of America (SCAA) definition of shade coffee.

\begin{tabular}{|c|c|c|c|c|c|c|}
\hline $\begin{array}{c}\text { Certification } \\
\text { program }\end{array}$ & $\begin{array}{c}\text { BelRus } \\
(5 \text { out of } 5) \dagger\end{array}$ & $\begin{array}{c}\text { IrlRes } \\
\text { (4 out of } 5 \text { ) }\end{array}$ & $\begin{array}{c}\text { IrlPrd } \\
(2 \text { out of } 5)\end{array}$ & $\begin{array}{c}\text { BelPrd } \\
(2 \text { out of } 5)\end{array}$ & $\begin{array}{c}\text { HamPrd } \\
(0 \text { out of } 5)\end{array}$ & $\begin{array}{l}\text { Status of } \\
\text { criteria }\end{array}$ \\
\hline SCAA Draft Shade Definition & $\begin{array}{l}\text { shade } \\
(3 \text { out of } 3) \neq\end{array}$ & $\begin{array}{l}\text { shade } \\
\text { (3 out of } 3 \text { ) }\end{array}$ & $\begin{array}{l}\text { shade } \\
\text { (3 out of } 3 \text { ) }\end{array}$ & $\begin{array}{l}\text { shade } \\
\text { (3 out of } 3 \text { ) }\end{array}$ & $\begin{array}{l}\text { not shade } \\
(2 \text { out of } 3)\end{array}$ & draft \\
\hline Rnfrst Alliance ECO-O.K. & $\begin{array}{l}\text { certify } \\
\text { ( } 8 \text { out of } 8)\end{array}$ & $\begin{array}{l}\text { certify } \\
\text { ( } 8 \text { out of } 8)\end{array}$ & $\begin{array}{l}\text { certify } \\
\text { ( } 8 \text { out of } 8)\end{array}$ & $\begin{array}{l}\text { border } \\
\text { ( } 7 \text { out of } 8)\end{array}$ & $\begin{array}{l}\text { reject } \\
(5 \text { out of } 8)\end{array}$ & in use \\
\hline Smithsonian Bird-Friendly & $\begin{array}{l}\text { certify } \\
\text { ( } 7 \text { out of } 7)\end{array}$ & $\begin{array}{l}\text { border } \\
\text { ( } 6 \text { out of } 7)\end{array}$ & $\begin{array}{l}\text { reject } \\
(5 \text { out of } 7)\end{array}$ & $\begin{array}{l}\text { reject } \\
(3 \text { out of } 7)\end{array}$ & $\begin{array}{l}\text { reject } \\
(3 \text { out of } 7)\end{array}$ & in use \\
\hline Mexican Shade Coffee & $\begin{array}{l}\text { certify } \\
\text { ( } 7 \text { out of } 7)\end{array}$ & $\begin{array}{l}\text { border } \\
\text { ( } 6 \text { out of } 7)\end{array}$ & $\begin{array}{l}\text { reject } \\
(4 \text { out of } 7)\end{array}$ & $\begin{array}{l}\text { reject } \\
(4 \text { out of } 7)\end{array}$ & $\begin{array}{l}\text { reject } \\
(2 \text { out of } 7)\end{array}$ & proposed \\
\hline Mexican Shade Coffee PLUS & $\begin{array}{l}\text { certify } \\
\text { ( } 7 \text { out of } 7)\end{array}$ & $\begin{array}{l}\text { reject } \\
(4 \text { out of } 7)\end{array}$ & $\begin{array}{l}\text { reject } \\
(4 \text { out of } 7)\end{array}$ & $\begin{array}{l}\text { reject } \\
(1 \text { out of } 7)\end{array}$ & $\begin{array}{l}\text { reject } \\
(2 \text { out of } 7)\end{array}$ & proposed \\
\hline
\end{tabular}

Note: Abbreviations are: BelRus, Belen Rustic; IrlRes, Irlanda Restoration; IrlPrd, Irlanda Production; BelPrd, Belen Production; HamPrd, Hamburgo Production; IrlFor, Irlanda Forest; and BelFor, Belen Forest.

$\dagger$ Indicates how many of the sets of criteria each management system is able to meet.

$\ddagger$ Indicates management system compliance with the criteria for each program.

shade coffee certification program based on the general categories shown in the Appendix (for evaluation based on individual criteria see Mas 1999). The only criterion not included is tree density per hectare, used only by ECO-O.K., which every management system passed easily. According to this evaluation, Belen Rustic is the only management system that could be certified by all five programs (Table 2). Hamburgo Production, on the other hand, would be rejected by all programs. The other three management systems (Irlanda Restoration, Irlanda Production, and Belen Production) had mixed results (Table 2).

\section{Bird and butterfly diversity analysis}

Fig. 1 shows average Bray-Curtis similarity values of birds for each management type in relation to as- sociated forest reserve. For Fig. 1, these values were transformed from the average dissimilarity value for each management practice (similarity $_{\mathrm{BC}}=1-$ dissimilarity $_{\mathrm{BC}}$ ) so the direction of response was the same as that shown for butterfly species richness. Using ANOVA, there were significant differences in BrayCurtis dissimilarity values to the associated forest avifauna among coffee management treatments but only Rustic coffee in Finca Belen had significantly lower dissimilarity values than the other management practices $(F=13.054$, df $=4,15, P<0.0001$, Fisher's PLSD (protected least significant difference) critical difference of 0.082 for $\alpha=0.05$ ). Fig. 2 shows the significantly higher species richness in frugivorous butterflies found in Belen Rustic (adapted from Mas and Dietsch 2003). Table 3 shows the abundance for each

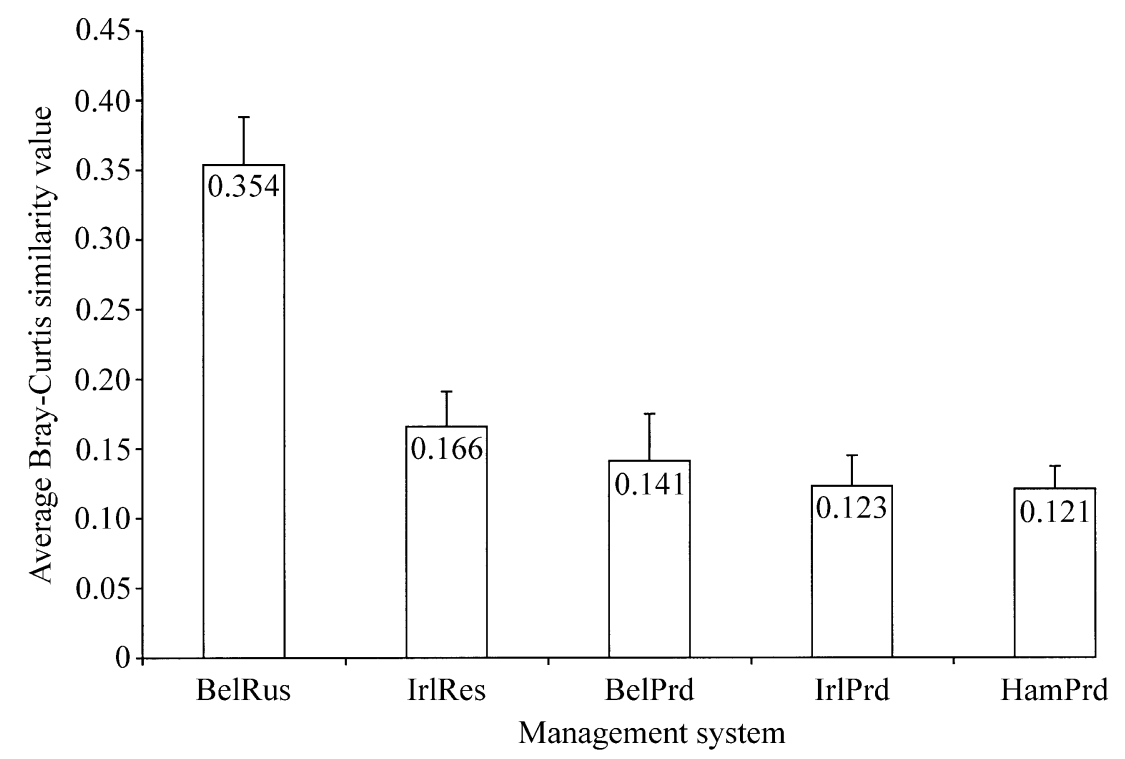

FIG. 1. Average Bray-Curtis similarity index values for birds in each management system. These were originally calculated as dissimilarity values by comparing each sample location with the avifauna observed in the associated forest reserve at each farm. Belen Rustic was found to be more similar to remnant forest patches than all other management systems $(\alpha=0.05)$. Error bars represent +1 SD. See Table 2 for abbreviations. 


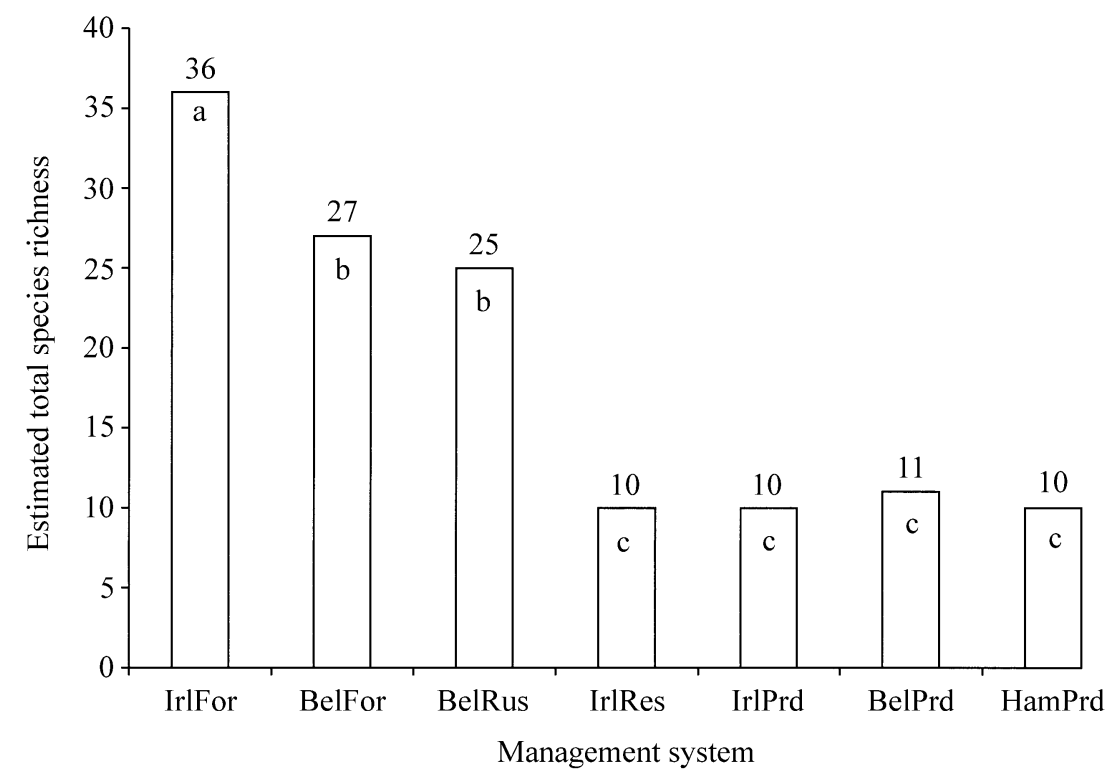

FIG. 2. Estimated total species richness of fruit-feeding butterflies (adapted from Mas and Dietsch [2003]). The letters located in each bar indicate mean values that are statistically distinct from one another $(\alpha=0.05)$. Species richness was compared using the software VACSYS to permute the order of acquisition of species used in constructing species accumulation curves. We performed 100 random permutations to generate 100 estimates of total species richness, and these estimates were then randomly reassigned into two groups 10000 times using the software RANDMEAN (see footnote 2). RANDMEAN then evaluates how frequently it is possible to achieve the difference as great or greater than the actual difference observed, and uses this probability (Bonferroni transformed at $\alpha=0.05$ to adjust for compounding error rate) to derive the $P$ values of statistically significant difference. See Table 2 for abbreviations.

bird species in each coffee management system. Though the observed species richness does not show a clear pattern in relation to management intensity, estimating the total species richness for each management system does show a similar pattern to that found using the Bray-Curtis, particularly for forest-associated birds (Dietsch 2003).

\section{DISCUSSION}

\section{Evaluation of coffee certification programs}

These results provide the first direct insight on the ability of certification programs to distinguish among management practices and identify those linked to higher levels of biodiversity, in this case for birds and fruit-feeding butterflies. Those seeking to promote market-based solutions to biodiversity loss in the tropics should be encouraged that this initial examination found Belen Rustic to be the only management system that meets the criteria of all certification programs (Table 2), as this was the only system that also had significantly higher diversity of fruit-eating butterflies and an avifauna more similar to that found in associated forest reserves.

Continuing at a coarse level of analysis, it is also encouraging that Hamburgo Production did not meet any of the five sets of criteria, as Mas and Dietsch (2003) identified this management system as significantly more intensive than the others in the study. This alone could mean a significant step forward for shade coffee certification and suggests that, if the Specialty Coffee Association's definition of shade coffee is enforced, the most intensive management systems would be excluded from consideration and marketing as shade-grown coffee, in spite of the fact that there may be shade trees present.

This said, an examination of the certification evaluations of the three intermediate systems reveals that further work is necessary to refine and bring together the criteria used in certification. This is most clear when comparing the three programs developed by the SMBC (Bird-Friendly, Mexican Shade, and Mexican Shade PLUS) with the ECO-O.K. program. The only intermediate system that could meet the criteria of the SMBC programs is Irlanda Restoration, which had a high enough species richness of shade trees and evidence of regeneration, although the average height of trees in this system $(8.98 \mathrm{~m})$ is considerably short of the required $12.0-\mathrm{m}$ minimum, suggesting that this system could be certified once the trees have had more time to grow. This suggests that the criteria used by SMBC are making the distinction outlined in the BirdFriendly program that "more diverse" commercial polyculture should be certified, and "less diverse" should not (Rice and McLean 1999). Furthermore, the results of this study suggest that the Mexican Shade program is also achieving its stated goals, because only the most rustic shade examined in this study meets the strict standards of the PLUS program, while the baseline 
standards could certify diverse commercial polyculture once the trees grow to sufficient height (Table 2).

On the other hand, two of the three intermediate systems meet the criteria of ECO-O.K., and Belen Production falls short only because of the absence of epiphytes (Mas 1999). The reason for this is that ECOO.K. sets no requirement for the average height of trees, and the criterion stating that $20 \%$ of the canopy be emergent trees taller than $15.0 \mathrm{~m}$ is included as a goal "in the medium term" not as a requirement (Rice and McLean 1999). While the details of these criteria indicate that farms could be certified by ECO-O.K. that could not be certified by the SMBC programs, this decision is consistent with the overall goal of ECOO.K. (Rice and Mclean 1999). ECO-O.K. has fashioned itself as an "engagement program" that does not set strict standards and turn away all those who cannot meet them, but rather works to include farmers, especially large producers, and encourage them toward greater sustainability (C. Wille, personal communication). With this in mind, ECO-O.K. can also be said to be achieving its certification goal of solidly endorsing the exemplary farms, turning away the most intensively managed, and working to include those in between. However, this study did not evaluate the effects of agrochemical use permitted by the ECO-O.K. program, which has been shown to have detrimental effects on biodiversity (O'Connor and Shrubb 1986, Avian Effects Dialogue Group 1994, Freemark and Boutin 1995, Gard and Hooper 1996).

Evaluation of specific criteria indicates the potential for several changes in the certification process. Separate analyses of the data in this paper suggest several criteria that warrant better representation in certification programs because they are particularly important for the diversity of butterflies and the presence of forest specialists: structure depth, average coffee height, and the presence of epiphytes (Mas 1999). Structure depth is the canopy thickness measured from the lowest branch of a canopy tree to the highest branch above the measurement location. Structural diversity of the shade canopy has always been recognized as important by certification programs, though most programs rely on a combination of other variables to serve as a proxy (such as the percentage of trees taller than a certain height and the presence of a stratum of emergent trees). The method to calculate structure depth described by Mas and Dietsch (2003) involves time and equipment requirements that may be too costly for certification. Therefore, it is probably more practical to acknowledge that structure depth is important for associated biodiversity and to identify related variables that can serve as proxies for this variable.

Mas (1999) showed a high correlation between structure depth and all proxies for canopy structure except one variable, the percent of the canopy taller than average $(r=0.049, P=0.839)$. This variable (used by the Bird-Friendly program) would be problematic if used alone because by looking for the percentage of trees taller than the backbone or average canopy trees, the measurement is against a sliding scale. For example, the backbone could be $7.94 \mathrm{~m}$, as in the case of Hamburgo Production, or $12.50 \mathrm{~m}$, as in the case of Belen Rustic. For this reason, every management system was able to meet this criterion (Mas 1999), suggesting that this criterion should only be used in conjunction with a minimum backbone height, as is required by the Bird-Friendly program.

An alternative variable that could be substituted instead is the presence of trees taller than $15 \mathrm{~m}$, currently recommended by ECO-O.K. and required by the Mexican Shade programs. In addition to being a standard that would not change based on changes in the management system, this variable was also found to be highly correlated with structure depth and with butterfly diversity (Mas 1999). Therefore, this seems an important criterion to include in the certification process, and in combination with other variables like average tree height and canopy closure, probably makes for a reasonable approximation of structure depth.

Although criteria for the coffee bushes are not currently part of any certification program, Mas (1999) indicated that coffee height was correlated with butterfly species richness. Managing the height and density of coffee bushes is not only a very site-specific process and related to coffee variety, but also draws on important tradition and superstition surrounding the productivity of a farm. In other words, it may be acceptable to set requirements for the height, density, and species richness of the trees that shade a coffee farm, but farmers are less likely to accept mandates for how they manage their coffee plants. Since shade coffee certification programs are still in the early stages of gaining acceptance from both consumers and producers, the addition of coffee-related criteria to the certification agenda could be an unnecessary complication. However, the results of Mas (1999), combined with the predominance of coffee bushes in the understory of any coffee agroforestry system, suggest that further study should be encouraged into the relationships between pruning and planting of coffee itself and associated biodiversity. Shade coffee certifiers should also be alert to this connection, and sensitive to the fact that, at some point in the evolution of these certification programs, coffee-related criteria may be necessary to achieve some conservation benefits.

The practice of clearing epiphytes from trees is widespread in the management of coffee, in spite of the evidence for birds that the presence of epiphytes may play an important role in supporting biodiversity on coffee farms (Nadkarni and Matelson 1989, Richter 1998). At present, all certification programs contain criteria prohibiting the removal of epiphytes from shade trees (Mas 1999). The wording of all versions of this criterion is difficult to enforce, however, and the evidence of the importance of epiphytes suggests 
TABLE 3. Observed bird species with number of individuals found in each treatment. Scientific and English nomenclature is based on AOU (1998).

\begin{tabular}{|c|c|c|c|c|c|c|c|c|c|}
\hline Scientific name & English name & BelFor & IrlFor & BelRus & IrlRes & IrlPrd & BelPrd & HamPrd & $\begin{array}{c}\text { Total } \\
\text { obser- } \\
\text { vations }\end{array}$ \\
\hline Buteo nitidus & Gray Hawk & 0 & 0 & 0 & 1 & 0 & 0 & 0 & 1 \\
\hline Columba flavirostris & Red-billed Pigeon & 0 & 4 & 0 & 4 & 2 & 0 & 2 & 12 \\
\hline Leptotila verreauxi & White-tipped Dove & 0 & 2 & 0 & 2 & 2 & 0 & 0 & 6 \\
\hline Aratinga strenua & Pacific Parakeet & 0 & 0 & 0 & 7 & 14 & 0 & 0 & 21 \\
\hline Piaya cayana & Squirrel Cuckoo & 1 & 0 & 0 & 2 & 0 & 1 & 0 & 4 \\
\hline Glaucidium brasilianum & $\begin{array}{l}\text { Ferruginous Pygmy- } \\
\text { Owl }\end{array}$ & 0 & 0 & 0 & 0 & 1 & 0 & 0 & 1 \\
\hline $\begin{array}{l}\text { Campylopterus hemileu- } \\
\text { curus }\end{array}$ & Violet Sabrewing & 0 & 0 & 0 & 1 & 0 & 0 & 0 & 1 \\
\hline Amazilia cyanura & $\begin{array}{l}\text { Blue-tailed Humming- } \\
\text { bird }\end{array}$ & 0 & 0 & 1 & 2 & 0 & 1 & 3 & 7 \\
\hline Amazilia rutila & $\begin{array}{l}\text { Cinnamon Humming- } \\
\text { bird }\end{array}$ & 0 & 0 & 0 & 1 & 0 & 0 & 0 & 1 \\
\hline Lampornis amethystinus & $\begin{array}{l}\text { Amethyst-throated } \\
\text { Hummingbird }\end{array}$ & 1 & 0 & 0 & 0 & 0 & 0 & 0 & 1 \\
\hline Trogon violaceus & Violaceous Trogon & 0 & 0 & 0 & 0 & 1 & 0 & 0 & 1 \\
\hline Trogon collaris & Collared Trogon & 4 & 0 & 0 & 0 & 0 & 0 & 0 & 4 \\
\hline Momotus momota & Blue-crowned Motmot & 4 & 0 & 5 & 3 & 2 & 0 & 0 & 14 \\
\hline Melanerpes aurifrons & $\begin{array}{l}\text { Golden-fronted Wood- } \\
\text { pecker }\end{array}$ & 0 & 0 & 0 & 0 & 0 & 0 & 4 & 4 \\
\hline Piculus rubiginosus & $\begin{array}{l}\text { Golden-olive Wood- } \\
\text { pecker }\end{array}$ & 1 & 3 & 0 & 1 & 0 & 0 & 0 & 5 \\
\hline Dryocopus lineatus & Lineated Woodpecker & 0 & 0 & 0 & 3 & 0 & 0 & 1 & 4 \\
\hline Synallaxis erythrothorax & $\begin{array}{l}\text { Rufous-breasted Spine- } \\
\text { tail }\end{array}$ & 0 & 0 & 0 & 0 & 3 & 1 & 1 & 5 \\
\hline $\begin{array}{l}\text { Anabacerthia variegati- } \\
\text { ceps }\end{array}$ & $\begin{array}{l}\text { Spectacled Foliage- } \\
\text { gleaner }\end{array}$ & 1 & 0 & 0 & 0 & 0 & 0 & 0 & 1 \\
\hline Automolus rubiginosus & Ruddy Foliage-gleaner & 5 & 0 & 0 & 0 & 0 & 0 & 0 & 5 \\
\hline $\begin{array}{l}\text { Sittasomus griseicapil- } \\
\quad \text { lus }\end{array}$ & $\begin{array}{l}\text { Olivaceous Woodcree- } \\
\text { per }\end{array}$ & 2 & 0 & 0 & 0 & 0 & 0 & 0 & 2 \\
\hline $\begin{array}{l}\text { Xiphorhynchus flavigas- } \\
\text { ter }\end{array}$ & $\begin{array}{l}\text { Ivory-billed Woodcree- } \\
\text { per }\end{array}$ & 1 & 1 & 4 & 0 & 0 & 0 & 0 & 6 \\
\hline Myiopagis viridicata & Greenish Elaenia & 0 & 1 & 0 & 0 & 0 & 0 & 0 & 1 \\
\hline Mionectes oleagineus & $\begin{array}{l}\text { Ochre-bellied Flycatch- } \\
\text { er }\end{array}$ & 10 & 10 & 4 & 1 & 0 & 0 & 0 & 25 \\
\hline $\begin{array}{l}\text { Rhynchocyclus breviros- } \\
\text { tris }\end{array}$ & Eye-ringed Flatbill & 0 & 1 & 0 & 0 & 0 & 0 & 0 & 1 \\
\hline $\begin{array}{l}\text { Tolmomyias sulphures- } \\
\text { cens }\end{array}$ & Yellow-olive Flycatcher & 1 & 4 & 1 & 4 & 4 & 6 & 4 & 24 \\
\hline $\begin{array}{l}\text { Platyrinchus cancromi- } \\
\text { nus }\end{array}$ & Stub-tailed Spadebill & 1 & 0 & 0 & 0 & 0 & 0 & 0 & 1 \\
\hline Contopus cinereus & Tropical Pewee & 0 & 0 & 1 & 1 & 0 & 1 & 0 & 3 \\
\hline Empidonax flavescens & Yellowish Flycatcher & 0 & 1 & 0 & 0 & 0 & 0 & 0 & 1 \\
\hline Myiarchus tuberculifer & $\begin{array}{l}\text { Dusky-capped Fly- } \\
\text { catcher }\end{array}$ & 0 & 0 & 0 & 2 & 2 & 0 & 1 & 5 \\
\hline Pitangus sulphuratus & Great Kiskadee & 1 & 0 & 0 & 0 & 0 & 0 & 1 & 2 \\
\hline Megarynchus pitangua & Boat-billed Flycatcher & 0 & 0 & 3 & 0 & 0 & 0 & 0 & 3 \\
\hline Myiozetetes similis & Social Flycatcher & 0 & 0 & 0 & 1 & 0 & 0 & 1 & 2 \\
\hline Tityra semifasciata & Masked Tityra & 1 & 1 & 0 & 0 & 0 & 0 & 1 & 3 \\
\hline Chiroxiphia linearis & Long-tailed Manakin & 1 & 1 & 0 & 0 & 0 & 0 & 0 & 2 \\
\hline Calocitta formosa & $\begin{array}{l}\text { White-throated Magpie- } \\
\text { Jay }\end{array}$ & 1 & 2 & 0 & 10 & 2 & 0 & 1 & 16 \\
\hline Cyanocorax yncas & Green Jay & 2 & 0 & 5 & 0 & 0 & 0 & 0 & 7 \\
\hline $\begin{array}{l}\text { Thryothorus maculipec- } \\
\text { tus }\end{array}$ & Spot-breasted Wren & 5 & 13 & 5 & 1 & 0 & 3 & 2 & 29 \\
\hline Thryothorus rufalbus & Rufous-and-white Wren & 3 & 4 & 11 & 2 & 0 & 6 & 0 & 26 \\
\hline $\begin{array}{l}\text { Thryothorus pleurostic- } \\
\text { tus }\end{array}$ & Banded Wren & 0 & 0 & 0 & 2 & 5 & 0 & 0 & 7 \\
\hline Thryothorus modestus & Plain Wren & 0 & 0 & 0 & 6 & 4 & 4 & 6 & 20 \\
\hline Troglodytes aedon & House Wren & 0 & 0 & 0 & 0 & 2 & 0 & 5 & 7 \\
\hline Henicorhina leucosticta & $\begin{array}{l}\text { White-breasted Wood- } \\
\text { Wren }\end{array}$ & 6 & 8 & 2 & 3 & 0 & 0 & 0 & 19 \\
\hline Catharus aurantiirostris & $\begin{array}{l}\text { Orange-billed Nightin- } \\
\text { gale-Thrush }\end{array}$ & 6 & 9 & 7 & 1 & 1 & 3 & 2 & 29 \\
\hline Turdus grayi & Clay-colored Robin & 1 & 10 & 6 & 16 & 12 & 5 & 19 & 69 \\
\hline Turdus assimilis & White-throated Robin & 8 & 12 & 4 & 0 & 0 & 0 & 0 & 24 \\
\hline Vireo plumbeus & Plumbeous Vireo & 2 & 0 & 2 & 4 & 0 & 0 & 0 & 8 \\
\hline Vireo flavoviridis & Yellow-green Vireo & 3 & 0 & 13 & 7 & 17 & 11 & 7 & 58 \\
\hline
\end{tabular}


TABle 3. Continued.

\begin{tabular}{|c|c|c|c|c|c|c|c|c|c|}
\hline Scientific name & English name & BelFor & IrlFor & BelRus & IrlRes & IrlPrd & BelPrd & HamPrd & $\begin{array}{c}\text { Total } \\
\text { obser- } \\
\text { vations }\end{array}$ \\
\hline Hylophilus decurtatus & Lesser Greenlet & 2 & 0 & 1 & 1 & 0 & 2 & 0 & 6 \\
\hline Myioborus miniatus & Slate-throated Redstart & 5 & 0 & 1 & 0 & 0 & 0 & 0 & 6 \\
\hline Basileuterus culicivorus & $\begin{array}{l}\text { Golden-crowned War- } \\
\text { bler }\end{array}$ & 10 & 9 & 5 & 0 & 0 & 0 & 0 & 24 \\
\hline Basileuterus rufifrons & Rufous-capped Warbler & 0 & 0 & 5 & 6 & 3 & 3 & 6 & 23 \\
\hline Cyanerpes cyaneus & $\begin{array}{l}\text { Red-legged Honey- } \\
\text { creeper }\end{array}$ & 0 & 0 & 0 & 2 & 10 & 8 & 16 & 36 \\
\hline Euphonia affinis & Scrub Euphonia & 0 & 0 & 2 & 0 & 0 & 0 & 0 & 2 \\
\hline Euphonia hirundinacea & $\begin{array}{l}\text { Yellow-throated Eu- } \\
\text { phonia }\end{array}$ & 1 & 4 & 1 & 2 & 0 & 1 & 2 & 11 \\
\hline Thraupis abbas & Yellow-winged Tanager & 0 & 0 & 1 & 7 & 5 & 2 & 1 & 16 \\
\hline Habia rubica & $\begin{array}{l}\text { Red-crowned Ant-Tan- } \\
\text { ager }\end{array}$ & 3 & 5 & 7 & 1 & 0 & 0 & 0 & 16 \\
\hline Piranga leucoptera & White-winged Tanager & 3 & 0 & 7 & 3 & 15 & 6 & 4 & 38 \\
\hline Saltator atriceps & Black-headed Saltator & 6 & 5 & 4 & 1 & 2 & 0 & 1 & 19 \\
\hline Melozone biarcuatum & $\begin{array}{l}\text { Prevost's Ground-Spar- } \\
\text { row }\end{array}$ & 0 & 0 & 0 & 0 & 0 & 0 & 5 & 5 \\
\hline Melozone leucotis & $\begin{array}{l}\text { White-eared Ground- } \\
\text { Sparrow }\end{array}$ & 15 & 4 & 15 & 1 & 0 & 4 & 0 & 39 \\
\hline Sporophila torqueola & $\begin{array}{l}\text { White-collared Seed- } \\
\text { eater }\end{array}$ & 0 & 0 & 1 & 0 & 1 & 0 & 0 & 2 \\
\hline Volatinia jacarina & Black-Blue Grassquit & 0 & 0 & 0 & 1 & 0 & 0 & 1 & 2 \\
\hline Diglossa baritula & $\begin{array}{l}\text { Cinnamon-bellied } \\
\text { Flowerpiercer }\end{array}$ & 1 & 0 & 0 & 0 & 0 & 0 & 0 & 1 \\
\hline Dives dives & Melodious Blackbird & 0 & 0 & 0 & 1 & 5 & 0 & 0 & 6 \\
\hline Quiscalus mexicanus & Great-tailed Grackle & 0 & 0 & 0 & 1 & 5 & 0 & 0 & 6 \\
\hline Molothrus aeneus & Bronzed Cowbird & 0 & 0 & 0 & 0 & 0 & 0 & 2 & 2 \\
\hline Icterus chrysater & Yellow-backed Oriole & 0 & 0 & 0 & 0 & 3 & 0 & 0 & 3 \\
\hline Icterus gularis & Altamira Oriole & 0 & 0 & 0 & 1 & 3 & 0 & 0 & 4 \\
\hline Icterus pectoralis & Spot-breasted Oriole & 0 & 0 & 0 & 1 & 1 & 0 & 0 & 2 \\
\hline Total no. observations & & 118 & 114 & 124 & 117 & 127 & 68 & 99 & 767 \\
\hline $\begin{array}{l}\text { Average no. individu- } \\
\text { als/point count }\end{array}$ & & 7.38 & 7.13 & 7.75 & 7.31 & 7.94 & 4.25 & 6.19 & 6.85 \\
\hline $\begin{array}{l}\text { Observed species rich- } \\
\text { ness }\end{array}$ & & 34 & 23 & 28 & 40 & 27 & 18 & 26 & 69 \\
\hline
\end{tabular}

Note: See Table 2 for abbreviations.

that it would be worthwhile to investigate some expanded and positive criterion that actually requires the presence of epiphytes. Standardizing this criterion will be difficult because the "norm" of epiphyte presence is highly variable, so further research is needed to determine how best to add more stringent requirements to the certification process for this important variable.

\section{Bird and butterfly diversity analysis}

For both butterflies and birds, this study suggests significantly higher indications of conservation success in the management system that meets the most restrictive shade criteria (Belen Rustic). For butterflies, as found by Mas and Dietsch (2003), estimated species richness is on par with associated forests and significantly higher than other production systems (Fig. 2). Using species richness as a gauge of conservation success has its limits, however. As pointed out by numerous authors in evaluating forest/ecosystem management programs, the presence of a species does not necessarily translate into a viable population or conservation success (temperate forests, Martin 1992, Donovan et al. 1995, Robinson et al. 1995; tropical forests, Gordon and Ornelas 2000). However, in lieu of productivity data, similarity indices that include a measure of abundance for each species, such as the Bray-Curtis index used for birds here, may provide a better characterization of the forest fauna than those based on species lists (Kempton 1979). Applying this index to birds as a target of conservation concern also finds greater similarity to the forest avifauna in Belen Rustic (Fig. 1). Consequently, the biodiversity data seem to mirror findings in the vegetation data and support the hypothesis that management practices that maintain a more diverse shade canopy can support higher levels of forest-associated biodiversity, and perhaps more importantly, can be identified by certification criteria.

This study sampled a gradient of management intensity, controlling in a general sense for landscape position through elevation and farm selection (all farms were located within larger coffee landscapes). Finding significant differences at one end of the gradient, in Rustic coffee, limits the generality of these results. Despite a small sample size, significant differences were found for this system, but additional landscape- 
level factors not measured by this study could have produced these findings. While pseudoreplication is an important consideration in field studies (Hurlbert 1984), particularly in human-managed landscapes, valuable insights can still be gained from small studies when combined with additional work (Oksanen 2001). Further research is merited to test the indications shown in this study and to explore additional factors that may influence biodiversity patterns within coffee agroecosystems, such as climate and landscape context.

\section{Linking conservation benefits to certification programs}

Forest or ecosystem management programs are evaluated based on how well management practices make progress toward specific conservation goals (Grumbine 1994). As agricultural systems seek to include similar conservation goals, they too should be accepted or rejected based on how well conservation benefits can be linked to management practices. In this study, a range of proposed certification programs were evaluated based on how their criteria matched up against specific management practices as measured by the vegetation found in each area. One approach toward identifying a successful certification program is to certify management practices that support a fauna more closely resembling what might be found in a less-managed forest from a similar landscape. In this case, those sets of criteria that best distinguish between the management systems would certify practices that produce a higher species richness for frugivorous butterflies and an avifauna with greater similarity to associated forest reserves.

One limitation in linking conservation success to certification programs encountered by this study is that programs are being evaluated in relation to one another. In this case, rustic organic coffee contains relatively more diverse fauna for forest birds and frugivorous butterflies than the other management practices evaluated. Though associated forests are used in this study to standardize comparisons, conservation benefits are more difficult to predict without more concrete objectives. A better approach would be to gauge each program against objective conservation standards based on realistic and explicit conservation goals. These goals can be derived from the levels of habitat use (breeding use, foraging habitat, or increased connectivity) associated with the management practice a program is seeking to encourage. If goals include viable reproduction, then certification programs should include criteria associated with protecting forest fragments that may serve as population sources.

Many farmers and farmer cooperatives include forest fragments as part of their land management, which may provide key resources for achieving particular conservation goals. The importance of a diverse landscape mosaic was recognized in the recent agreement on conservation principles for coffee production (Consumer's
Choice Council et al. 2001), and should be codified into certification criteria as has been discussed (Xalapa meeting). Research is also needed to gauge the relative benefits for such variables as reproductive success and annual survival from forest conservation (or restoration) and those derived from improvements in coffee management. This study suggests that despite reaching common ground on general principles related to coffee certification (Consumer's Choice Council et al. 2001), these programs still differ in the shade management intensity they would certify, which could translate into different conservation benefits. So, just as all shade is not created equal, all certified shade-grown coffee programs might not produce the same conservation benefits.

This study suggests that eco-labeling efforts that use measurable criteria based on habitat characteristics can be verified and monitored by surveying biodiversity. While academics cannot realistically serve as thirdparty auditors, applied ecologists should test the underlying assumptions and hypotheses implicit in ecologically sustainable certification efforts. Conservation biologists can help define habitat use expectations associated with program goals and in designing monitoring programs appropriate for measuring these goals. While birds of conservation concern have been observed in coffee grown with a shade component (Dietsch 2000), how these birds use coffee as habitat has yet to be examined. The approaches presented here are probably best used for program goals associated with differing levels of transitory habitat use such as foraging or dispersal. In order to evaluate whether viable habitat is provided for breeding populations of organisms displaced by coffee production, more intensive monitoring is required to gauge reproductive success both expected in original forest and found in a given coffee management system. Future work should focus on identifying benchmarks for biodiversity conservation associated with different habitat use expectations. In the meantime, this study suggests that consumer confidence in shade coffee certification is warranted, especially for programs using the strongest certification criteria.

\section{CONCLUSION}

The results of this study suggest that shade coffee certification programs seem, on the whole, to be successfully identifying coffee farms of conservation significance, and with the inclusion of some of the fine tuning recommended previously, they could maximize the ecological relevance of their criteria. It is critical to bear in mind, however, that this study relied on a limited number of farms and focused on a range of coffee management systems within the Soconusco region of Chiapas, Mexico. The results therefore represent only a case study from one relatively small region in northern Latin America. Similar evaluations should therefore be performed throughout the world's coffee 
growing regions, and more exhaustive, multisite analyses conducted to see where the general trends presented here hold true and where they falter.

The differences between certification programs that emerged from this study reflect not a difference in the ability of each program to achieve its goals, but rather philosophical differences underlying conservation strategies for the coffee sector. The potential success of these different approaches will depend on how each affects consumer and producer behavior, an area requiring more study (Messer et al. 2000). This paper cannot resolve the debate over whether conservation will be best achieved by including more large-scale producers so as to work with them toward sustainability, or by setting standards high, and hoping a price premium can encourage participation. What is worth comment, however, are the ways that the products of all certification programs are being marketed. In every case, and even for uncertified coffee, where roasters are trying to capitalize on the concept of shade coffee, the images invoked for customers are of the rustic farms that have been shown to support tropical biodiversity. The results of this study suggest that it is only on these rustic farms that significantly greater levels of bird and butterfly diversity are found. The debate on how to distinguish between shade coffee farms that contribute to overall biodiversity conservation and those that compromise it must continue. However, if coffee roasters and retailers are interested in selling an image of shadegrown coffee that includes tall forests rich in bird and butterfly diversity, they may best maintain consumer confidence if they buy coffee certified as coming from the rustic farms where this image seems to be best represented.

\section{ACKNOWLEDGMENTS}

We wish to thank Walter Peters and the ISMAM cooperative for allowing us to conduct this study on their farms and for giving us support throughout the time that we were conducting the study. We also thank ECOSUR-Tapachula, Dr. Guillermo Ibarra-Núñez, and Alvaro Garcia-Ballinus for providing logistical support and access to laboratory facilities, and Dr. Ivette Perfecto and Dr. John Vandermeer for advice and consultation throughout the process of research and writing. Dr. Russell Greenberg from Smithsonian Migratory Bird Center also gave helpful comments on a final version of this paper. Darci Andresen, Jay West, and Daniel Griffith helped with data collection in the field. Dr. Gary Fowler and Matthew Kotchen assisted with analysis. This study was partially funded by the Latin American and Caribbean Study Program, the School of Natural Resources and Environment and the Horace Rackham Graduate School of the University of Michigan. In addition, this work partially funded by the Kalamazoo Audubon Society and NSF grant no. CEB-9981526.

\section{Literature Cited}

AOU (American Ornithologists' Union). 1998. Checklist of North American birds. Seventh edition. American Ornithologists' Union, Washington, D.C., USA.

Avian Effects Dialogue Group. 1994. Assessing pesticide impacts on birds. Final report of the Avian Effects Dialogue Group 1988-1993. Resolve, Washington, D.C., USA.
Bray, D. B., J. L. P. Sanchez, and E. C. Murphy. 2002. Social dimensions of organic coffee production in Mexico: lessons for eco-labeling initiatives. Society and Natural Resources 15:429-446.

Bray, J. R., and J. T. Curtis. 1957. An ordination of the upland forest communities of S. Wisconsin. Ecological Monographs 27:325-349.

Celis, F., R. Cobo, A. Gárcia, P. López S., J. Moguel, A. J. Olvera, L. Paré, L. P. Paredes, F. P. Arce, G. Ejea, and L. Hernández. 1991. Cafetaleros: la construcción de la autonomía. Coordinadora Nacional de Organizaciones Cafetaleras, Tabasco 262-301, colonia Roma, México, D.F.

CEC (Commission for Environmental Cooperation). 1999. Measuring consumer interest in Mexican shade-grown coffee: an assessment of the Canadian, Mexican and US Markets. White paper prepared for the Commission for Environmental Cooperation, Montreal, Quebec, Canada.

Consumer's Choice Council, Conservation International, Rainforest Alliance, Smithsonian Migratory Bird Center, and Summit Foundation. 2001. Conservation principles for coffee production. White paper prepared for the Consumer's Choice Council, Washington, D.C., USA.

Dettmers, R., D. A. Buehler, J. G. Bartlett, and N. A. Klaus. 1999. Influence of point count length and repeated visits on habitat model performance. Journal of Wildlife Management 63:815-823.

Dietsch, T. V. 2000. Assessing the conservation value of shade-grown coffee: a biological perspective using Neotropical birds. Endangered Species Update 17(6):122-124.

Dietsch, T. V. 2003. Conservation and ecology of birds in coffee agroecosystems of Chiapas, Mexico. Dissertation. University of Michigan, Ann Arbor, Michigan, USA.

Donovan, T. M., F. R. Thompson III, J. Faaborg, and J. R. Probst. 1995. Reproductive success of migratory birds in habitat sources and sinks. Conservation Biology 9:13801395.

Drapeau, P., A. Leduc, and R. McNeil. 1999. Refining the use of point counts at the scale of individual points in studies of bird-habitat relationships. Journal of Avian Biology 30:367-382.

Freemark, K., and C. Boutin. 1995. Impacts of agricultural herbicide use on terrestrial wildlife in temperate landscapes: a review with special reference to North America. Agriculture, Ecosystems, and Environment 52:67-91.

Gard, N. W., and M. J. Hooper. 1996. An assessment of potential hazards of pesticides and environmental contaminants. Pages 294-310 in T. E. Martin and D. M. Finch, editors. Ecology and management of Neotropical migratory birds: a synthesis and review of critical issues. Oxford University Press, Oxford, UK.

Gordon, C. E., and J. F. Ornelas. 2000. Comparing endemism and habitat restriction in Mesoamerican tropical deciduous forest birds: implications for biodiversity conservation planning. Bird Conservation International 10:289-303.

Greenberg, R., P. Bichier, A. C. Angon, and R. Reitsma. 1997a. Bird populations in shade and sun coffee plantations in Central Guatemala. Conservation Biology 11:448459.

Greenberg, R., P. Bichier, and J. Sterling. 1997b. Bird populations in rustic and planted shade coffee plantations of eastern Chiapas, Mexico. Biotropica 29:501-514.

Grumbine, R. E. 1994. What is ecosystem management? Conservation Biology 8:27-38.

Hurlbert, S. H. 1984. Pseudoreplication and the design of ecological field studies. Ecological Monographs 54:187211.

Hutto, R. L., S. M. Pletschet, and P. Hendricks. 1986. A fixedradius point count method for nonbreeding and breeding season use. Auk 103:593-602. 
Kempton, R. A. 1979. Structure of species abundance and measurement of diversity. Biometrics 35:307-322.

Kortbech-Olesen, R. 2000. Export opportunities of organic food from developing countries. International Federation of Organic Agriculture Movements (IFOAM), Tholey-Theley, Germany. [Online: 〈http://www.ifoam.org/orgagri/ worldorganics_2000_conference.html $\rangle$.]

Magurran, A. E. 1988. Ecological diversity and its measurement. Princeton University Press, Princeton, New Jersey, USA.

Martin, T. E. 1992. Breeding productivity considerations: what are the appropriate habitat features for management? Pages 455-473 in J. M. Hagan III and D. W. Johnston, editors. Ecology and conservation of Neotropical migrant landbirds. Smithsonian Institution Press, Washington, D.C., USA.

Mas, A. H. 1999. Butterflies as biodiversity indicators and shade coffee certification in Chiapas, Mexico. Thesis. University of Michigan, Ann Arbor, Michigan, USA.

Mas, A. H., and T. V. Dietsch. 2003. An index of management intensity for coffee agroecosystems to evaluate butterfly species richness. Ecological Applications 13:1491-1501.

Messer, K. D., M. J. Kotchen, and M. R. Moore. 2000. Can shade-grown coffee help tropical biodiversity? A market perspective. Endangered Species Update 17(6):125-131.

Moguel, P., and V. M. Toledo. 1996. El café en México: ecología, cultura indígena y sustentabilidad. Ciencias $\mathbf{4 3}$ : $40-51$.

Moguel, P., and V. M. Toledo. 1999. Biodiversity conservation in traditional coffee systems in Mexico. Conservation Biology 12:1-11.

Nadkarni, N. M., and T. J. Matelson. 1989. Bird use of epiphyte resources in Neotropical trees. Condor 91:891-907.

O'Connor, R. J., and M. Shrubb. 1986. Farming and birds. Cambridge University Press, Cambridge, UK.

Oksanen, L. 2001. Logic of experiments in ecology: is pseudoreplcation a pseudoissue? Oikos 94:27-38.

Payne, R. B., J. L. Woods, M. Siddall, and C. S. Parr. 2000. Randomization analyses: mimicry, geographic variation and cultural evolution of song in brood-parasitic strawtailed whydahs, Vidua fischeri. Ethology 106:261-282.

Pérezgrovas, V., R. Marvey L., W. Anzueto A., F. Rodríguez L., and E. Gómez H. 1997. El cultivo de café orgánico en La Unión Majomut. Red de Gestión de Recursos Naturales y Fundación Rockefeller, Mexico City México.

Perfecto, I., A. Mas, T. Dietsch, and J. Vandermeer. 2003. Conservation of biodiversity in coffee agroecosystems: a tri-taxa comparison in shade coffee in southern Mexico. Biodiversity and Conservation 12:1239-1252.

Perfecto, I., R. A. Rice, R. Greenberg, and M. E. Van der Voort. 1996. Shade coffee: a disappearing refuge for biodiversity. BioScience 46:598-608.

Perfecto, I., and R. Snelling. 1995. Biodiversity and the transformation of a tropical agroecosystem: ants in coffee plantations. Ecological Applications 5:1084-1097.

Petit, L., D. Petit, V. A. Saab, and T. E. Martin. 1994. Fixedradius point counts in forests: factors influencing effectiveness and efficiency. Pages 51-59 in C. J. Ralph, S. Droege, and J. Sauer, editors. Monitoring bird population trends by point counts. USDA Forest Service General Technical Report PSW-GTR-149.

Rice, P. D., and J. McLean. 1999. Sustainable coffee at the crossroads. White paper prepared for the Consumer's Choice Council, Washington, D.C., USA.

Rice, R. A., and J. R. Ward. 1996. Coffee, conservation, and commerce in the Western Hemisphere. Smithsonian Migratory Bird Center and Natural Resources Defense Council, New York, New York, USA. [Online: 〈http://www. nrdc.org/health/farming/ccc/cptinx.asp $\rangle$.]

Richter, C. 1998. Breeding success and nest sites of the common bush-tanager (Chlorospingus opthalmicus opthalmicus) in shaded coffee plantations of Veracruz, Mexico. Thesis. University of Michigan, Ann Arbor, Michigan, USA.

Robinson, S. K., F. R. Thompson III, T. M. Donovan, D. Whitehead, and J. Faaborg. 1995. Regional forest fragmentation and the nesting success of migratory birds. Science 267:1987-1990.

SAS Institute. 1998. StatView. Version 5.0.1. SAS Institute, Cary, North Carolina, USA.

SMBC (Smithsonian Migratory Bird Center). 1998. Shade management criteria for "Bird-Friendly" coffee. Smithsonian Migratory Bird Center, Smithsonian Institution, Washington, D.C., USA.

Toledo, V. M., and P. Moguel. 1996. Searching for sustainable coffee in Mexico: the important of biological and cultural diversity. Pages 163-173 in R. A. Rice, A. M. Harris, and J. McLean, editors. Proceedings from the First Sustainable Coffee Congress. Smithsonian Migratory Bird Center, Smithsonian Institution, Washington, D.C., USA.

Wunderle, J. M., and S. C. Latta. 1996. Avian abundance in sun and shade coffee plantations and remnant pine forest in the Cordillera Central, Dominican Republic. Ornithologia Neotropical 7:19-34.

\section{APPENDIX}

Certification criteria evaluation tables for shade coffee farms are available in ESA's Electronic Data Archive: Ecological Archives A014-009-A1. 